\title{
The Humanitarian Imperative in Disaster Management-A Memorial Tribute to Professor Peter Safar
}

\author{
S.W.A. Gunn, MD, MS, FRCSC, Dr h c
}

\section{President, International Association for Humanitarian Medicine \\ President Emeritus, World Association for Disaster and Emergency Medicine}

Invited by the University of Pittsburgh as Special Orator at the Fifteenth Peter and Eva Safar Lectureship in Medical Sciences

Correspondence:

S. William A. Gunn

E-mail: swagunn@bluewin.ch
This is an emotional and humbling occasion to be at the illustrious University of Pittsburgh to deliver the Special Oration honoring the indefatigable pioneers in life-enriching concepts and processes, Peter and Eva Safar, and to highlight Peter's contributions to humanitarian medicine.

I am grateful to the Dean for the honor done me personally, and to the World Association for Disaster and Emergency Medicine, which Professor Safar and a group of friends founded with great vision some decades ago. I would like to associate in this venture, the World Health Organization; I do this with much pleasure as this has been the theatre of my international humanitarian work and the institution where I first met Peter Safar, and where we set our dreams.

It is traditional that a named lecture begin with some evocation of the person in whose name it is given. It always has fascinated me how, sometimes, certain names or words fit their bearers like a well cut suit. We are gathered here for the Safar International Resuscitation Research Conference. What a wonderful word, Resuscitation, from the Latin Suscitare, "to elevate", "to restore", "to revive", whence "to reanimate". Could a University have a nobler calling? And does this not apply also to Peter Safar? In 1976, he and Dr. Negovsky of Moscow coined the term "disaster reanimatology" for our profession. Reanimatology, from the Greek "anima", spirit, life, whence "giving spirit", "'giving life", and making life worthwhile.

This is what one immediately thinks of when one evokes the names of Pittsburgh and Safar: Reanimation, revitalization, resuscitation, enriching life: Ut vitam habeant, abondanteus habeant ${ }^{2}$ And this is why it is such a significant occasion for me to be on this rostrum, in this School of Medicine.

I am sure each one of you present here is, in one way or another, involved in providing life support to the critically ill, in emergency aid to the injured, in relief to victims of conflict, in assistance to those stricken by disaster, or research to improve all these actions. You are all well-versed in the clinical, academic, scientific, and organizational aspects of major emergencies. I should therefore like to focus my remarks not on the technical aspects of international assistance, but on the humanitarian imperative of disaster management.

Disasters, unfortunately, and help, fortunately, are as old as humanity. As long as man has had a heart, some adrenalin and a physiological reflex for protection, he has had compassion and an urge to bring succour to those in distress.

Distress, I am afraid, is not in short supply today. In fact, the frequency and magnitude of disasters and major emergencies steadily is increasing throughout the world, imposing a heavy strain on the essential services and much suffering in individual countries and the international community. There are, currently, in the world's "disaster belt" of earthquakes, cyclones and desertification, over 100 developing countries, few if any of which have

"That they may have life, and have it more abundantly. John 10:10. 
the technical knowledge, planning capacity, and necessary resources to cope with such onslaughts. Add to these the constant risk of major technological disasters and the current complex sociopolitical upheavals, and we have a spaceship Earth in chronic state of emergency.

Historically, assistance in such emergencies has evolved from early wound dressing and pain relief, to specialized techniques like Emergency and Disaster Medicine; to institutionalized mechanisms like the Red Cross; to newer social and political concepts of aid, as humanitarian intervention; and to more productive strategies, as disaster prevention.

Whatever the motivation, whatever the magnitude of the emergency, whatever the scale of relief, and however well intentioned the goodwill, disaster response must, if it is to be efficient and effective, primarily have a proper scientific base and technical underpinning.

Most of you in this audience have too often heard my views on the absolute necessity in emergency and disaster medicine of a technical and managerial infrastructure both in men and matariel. In any case such a call in Pittsburgh would be entirely redundant.

At the same time, I feel at ease in this University, in concentrating on the humanistic aspects of our work, for it has been here that Peter Safar not only forged the science of disaster reanimatology, but also led the way to transforming disaster medicine to international humanitarian activism.

During the past few decades or so, our ways of thinking about disasters and our methods of tackling disasters have changed dramatically, and fundamental developments are now taking place in worldwide disaster management.

1. Major emergencies and disasters are no more considered fatalistic phenomena, but rather as foreseeable events that can be prevented;

2. Those who provide assistance now look upon it not as a gesture of sympathy, but as a duty based on mutual aid;

3. The stricken nations and communities are claiming relief not as a charity but as a right;

4. Disaster aid is being seen not as an ad hoc, emergency repair episode but as an essential factor in long-term development;

5. The world community now perceives emergency relief not as a magnanimous contribution but as a humanitarian obligation;

6. Armed forces are being "re-cycled" from traditional combat duties to peace-keeping and peace-making functions; and

7. The medical community, which had long felt the strength of the human factor, is already calling disaster medicine, "peace medicine".

These, I contend, represent a quantum leap forward in human, medical, and international relations.

Let me examine, with you, this humanitarian postulate of our specialty. And I unreservedly rank humanitarian and disaster medicine as specialties, that have come of age but which are young enough to provide dream, action, and growth. I consider it a privilege to be associated with the world's major organizations devoted to these two exciting endeavors, and I thank you all for contributing to this progress.

"Humanitarian", I was saying. It is paradoxical that war has engendered peaceful organizations and that new kinds of conflict now are engendering new concepts of peaceful response.

The International Committee of the Red Cross was born out of the battlefield of Solferino (1359) and resulted in the Geneva Conventions on decency between belligerents. World War I produced the League (now Federation) of Red Cross and Red Crescent Societies, and, of course, the United Nations, and its medical arm, the World Health Organization, were born out of the ashes of World War II. But, the paradox doesn't end there, for Peter Safar also is a product of World War II. As a surgical trainee in embattled Europe, noting all the dying people around him, Peter wondered why one couldn't turn the death process around. And for the past 50 years, he has been working exactly on that process reversal. And we all know with what humanism, imagination and scientific achievement.

Let us come back to the aftermath of the 2nd World War. Its end came none too soon, but it also resulted in the Cold War, which, until some years ago, completely galvanized international politics, quasi-paralyzed the UN, distorted country-to-country intercourse, polarized all national expenditures and limited humanitarian action.

Happily with the end of the cold war, all this has changed. But, the world is faced with a new situation, with new problems, and new challenges. The new situation is that thermonuclear competition between the two major nuclear powers is virtually over, and that war between the leading nations of the East and West is most unlikely. It is no longer disrespectable among serious analysts to consider the probability of a nuclear-free world, and in large measure international peace is at hand.

The new problems are equally real, but of an entirely different nature, with a most destabilizing effect on peace and security. One problem is the continuing presence of nuclear weapons under more fragile circumstances than before, and the other is the explosion of ethnic conflicts and centrifugal movements in many parts of the world.

In contrast with the relative calm on the international scene, intra-country strife of varying origins shows that the United Nations and the international community are illprepared for such new situations. For all their horrors, these internal conflicts do not threaten international peace; the strife in Bosnia did not plunge Europe into war, the fighting in Afghanistan is not an international war, and no outside power is invading Somalia, which is torn among its local warlords.

States, the international community, the United Nations, the disaster management organizations, relief societies and even the military doctors have to adapt to these changing circumstances and changing needs.

The changes perhaps affect least the non-governmental organizations, scientists and practitioners of disaster medicine, like us, than the government-based and diplomatical- 
ly tied institutions. For disaster medicine is a humanitarian, emergency help and health providing activity, related to man's suffering and unrelated to any political ideology or governmental ties. Somewhat in like manner, liberated from the straight-jacketing political constraints of the excold war, the United Nations too is re-defining its capacities: it is moving from peace-keeping to peace-building, and this is to its credit.

This evolution, perhaps revolution, is recent. On 05 April 1991, the Security Council made a historic decision that has established new rules in international relations and intra-national behavior, and which has a tremendous impact on emergency assistance. Resolution 688 now gives the international community the "right to intervene"-le droit d'ingérence - on humanitarian grounds or for urgent human-rights protection.

Furthermore, arid this concerns more the non-governmental, voluntary, and emergency facilities like IRRC and WADEM, General Assembly Resolution 4-131 formally recognizes the role of NGOs in providing humanitarian aid in "... food, medicines, and health care for which access to victims is essential".

These are landmark decisions. It was on the strength of Resolution 688 that outside forces were able to intervene in Northern Iraq in favor of the suffering Kurds, that made it possible for U.S. and other forces to mount Operation Restore Hope in Somalia, and that allow some kind of help to be channeled to Bosnia-Herzegovina, however insufficient this may be. It was also through this that this Center's team could go to Sarajevo.

As a WHO man, I note with some pride that this takes us full circle to the basic precept of the World Health Organization: that health and security are a human right. Indeed the right to health is enshrined in WHO's Constitution, which states:

The enjoyment of the bighest attainable standard of bealth is one of the fundamental rights of every being and

The health of all peoples is fundamental to the attainment of peace and security.

Other United Nations instruments expand on and strengthen these ideals: Article 25 of the Universal Declaration of Human Rights states:

Everyone has the right to a standard of living adequate for the bealth and well being of bimself and of his family, including food, clothing, housing and medical care and necessary services, and the right to security ... in circumstances beyond his control.

Principle 4 of the UN Declaration of the Rights of the Child states:

The child shall enjoy the benefits of social security. He shall be entitled to grow and develop in health... [and] have the right to adequate nutrition, housing, recreation, and medical services.

And the Universal Declaration on the Eradication of Hunger and Malnutrition adds:

Every child has the inalienable right to be free from bunger and malnutrition....
All these lend logic and credence to the WHO's definition of Health which, back in 1948, seemed so revolutionary, indeed controversial, but which in the light of today's concepts and experiences, responds exactly to the challenges and philosophy of modern medicine:

Health is a state of complete physical, mental and social well-being and not merely the absence of disease or infirmity.

Seen from the battlefield, from the flooded land, from the refugee camp or the disaster site, then, one does not necessarily have to be injured or bleeding to be considered lacking in health. The mere fact of being in a disaster situation, with the attendant mental and social stresses, is in itself a lack of well-being; a well-being to which the stricken person has a right, and towards which the medical profession has a dury.

These international instruments and professional expressions of intent have taken more substance concerning disasters since December 1991, when General Assembly Resolution 46/182 created the UN Department of Humanitarian Affairs to combat more effectively the major emergencies. DHA supersedes UNDRO and officially establishes the humanitarian imperative. At WHO, the department's new name is Emergency and Humanitarian Action.

These then are some of the bases-and to us doctors some of the necessary underpinnings - of the evolving doctrine of humanitarian intervention in disasters. Translated into medical terms, there is already a feeling that Disaster Medicine is Humanitarian Medicine.

Naturally these ideas will not be enthusiastically espoused everywhere. The right to intervene, in particular, cannot be expected to receive universal acclaim, and even just recently at the International Conference on Human Rights in Vienna it was opposed by some, who perhaps feared for their seats. For the former Minister of Health of France, Dr. Bernard Kouchner, "...It is a dream. It is a sort of utopia. But, it is obviously the only way". Former national-security adviser to President Carter, Zbigniew Brzezinski, also welcomes the concept and considers that "intervention is the flip side of interdependence". And are we not living in an interdependent world?

To be productive, credible and impartial, any intervention must be decided upon and carried out under the strictest vigilance and unbiased adherence to international precepts in order to avoid abuses or excesses and not invite excuses. For, as one observer from the Third World has put it, "intervention, however well meaning, must not become a new form of colonialism; we can only accept it as a shortterm solution". This is in fact capital: an emergency intervention, whether medical, social or political, must be seen as just that-an emergency, with strictly specified conditions and limits to it in scope, time, and place; a humanitarian, not a political action.

Where does our profession stand in all this? Obviously the old problems due to nature's fury and man's folly will be with us on an ever-increasing scale. On the other hand, the new challenges of scientific progress and humanitarian 
service will at once open new vistas and bring new satisfactions in emergency relief.

Already some years ago, in Vol. 1, No. 1 of Prehospital and Disaster Medicine that he founded, Peter Safar was advocating a humanitarian service for the military in disaster situations, and as recently as in another issue of the same Journal he again reminded us that traumatology, disaster management, and indeed the whole of medicine are not hermetically compartmentalized disciplines, but rather a way of life and a science for health with a humanitarian commitment.

If we, as health professionals, can achieve these standards and meet the old and new challenges with honesty, competence, equanimity and humanism, as Peter and Eva have done, then we shall have made our small step on this spaceship Earth.

\section{References}

1. Butros-Ghali B: From peace-keeping. to peace-building. Lecture by the Secretary General. UN document FR/SC/SM/1330, May 1992.

2. Del Mundo $F$ : The role of the military in humanitarian emergencies. Refugees 1993;91:19-21.

3. Gunn SWA: Disaster medicine and emergencies. The international community's response. J Irish College Phys and Surgeons 1988;17:141.

4. Gunn SWA: La medecine des catastrophes: une nouvelle discipline. Helvetica Chirurgica Acta 1985;52:11.

5. Gunn SWA: The Effects of Nuclear Disaster on Health. In: Otsuka T, Yamamoto Y, Ninomiya N (eds): Further Aspects of Disaster Medicine. Herusu Publications, Tokyo, p. 993.

6. Gunn SWA: Quantifiable effects of nuclear war on health and society. Annals of the Mediterranean Burns Club 1988;1:175.

7. Gunn SWA: The Right to Health. Cemec Monographs No. 2., European Centre for Disaster Medicine, San Marino, 1989.

8. Gunn SWA: The scientific basis of disaster management. Disaster Prevention and Management Journal 1992;1(3): 16-21.

9. Gunn SWA: Il presupposto umanitario nel soccorso delle catastrofi a livello internazionale. Oplitai, Ital J Emerg 1993;5:7-11.

10. Gunn SWA: Humanitarian, non-combat role for the military. Prehosp Disast Med 1994;9(2):S46-\$48.

11. Pretto EA, Begovic M: Mission to Sarajevo. Prehosp Disast Med 1994;9(2):S11-S12.

12. Safar P: Military-civilian collaboration in disaster medicine. Prehosp Disast Med 1985:1(1):4.

13. Safar P: Disaster medicine and wartorn former Yugoslavia. Prehosp Disast Med 1994;9(2):91-93.

14. Sullivan S: A right to intervene? Newsweek, 16 January 1993.

15. World Health Organization, Basic Documents, WHO, 1992. 